\title{
The Development of Children and Family Policy in Estonia from 1945 to 2000
}

\author{
MARE AINSAAR \\ Lecturer of Social Policy \\ Tartu University, Estonia
}

\begin{abstract}
The paper gives an overview of the formation of Estonian family policy in the period from 1945 to 2000. Deeper analyses are dedicated to the most recent decade and to the factors which have influenced family policy and the main objects of discussion. For that purpose statistics and interviews with policy makers are analysed. The paper comes to the conclusion that child and family policy carries traces of history, different institutions and traditions. Family policy has been classsified according to time period: $1945-$ 1970, 1970-1990, and 1990 to present. The main characteristics of the most recent decade's family policy include comparatively generous child benefits, a great dependency of policy on political decisions, and the development of an initially plain and simple children's and family policy towards a more complicated one.
\end{abstract}

Keywords: family policy, institutions, child benefits, day care, Estonia

\section{Introduction}

The aim of this paper is to give an overview of the formation of Estonian family policy in the period from 1945 to 2000. Deeper analyses are dedicated to the most recent decade. The main research question is how - which factors have influenced family policy and what have been the main objects of discussion.

A large portion of modern family policy literature is dedicated to the comparison of family policy in different countries (Wennemo 1992; Kamerman \& Kahn 1993; Gauthier 
1996; Stropnik 2000; Forssén 2000), estimation of the effectiveness of family policy in poverty reduction (Kangas \& Ritakallio 1998; Kangas 2000; Forssén 2000), and the impact of family policy on fertility (Cigno 1991; Gustafsson \& Meisaari-Polsa 1991; Gauthier \& Hatzius 1997; Chesnais 1998; Qvortrup, J. 1999).

There are several recent works on the classification of Estonian family policy in the framework of different European countries (Forssén 2000; Stropnik 2000) and the influence of policy on fertility (Ainsaar \& Oras 2000). Analysis shows that Estonian family policy is closest to that of other post-Socialist countries. The similarity of Estonian child and family policy to East-European countries allows the assumption that historical background has a strong influence on the formation of family policy. The last 10 years of policy formation in turn have been dependent on the many uncommon obstacles in those countries.

For 50 years, Estonia belonged to Soviet Union. Most family policy in the Soviet Union was unified. This provides the possibility of using the Estonian case study as an example of typical development of post-Soviet national policy. Still, it is well-known that even in the Soviet Union there were minor differences in the timing and amount of benefits (Jones \& Grupp 1987), which should warn us away from making easy conclusions. This is first time that the different aspects Estonian family policy are being analysed in a historical perspective.

The paper follows the general framework of public policy analyses and focuses on the history of family policy institutions and policy discussions. Special attention is given to the development of child allowances, parental leave and day-care arrangements as the most important policy measures. The impact of public opinion and different political parties are analysed only in the contemporary period.

Interviews with previous policy makers were conducted in January - June 2000.

\section{Definition of children and family policy}

There is no unequivocal definition of children and family policy. Different authors and frameworks employ words like "family policy", "children policy", "children's rights approach" etc.

General consensus exists only in that family policy belongs to the larger context of overall social policy and welfare state approach. Even in the framework of social policy's well-known classifications, the position of children and family policy is less clear than in other social policy areas (Gauthier 1996). 
In general, family policy is understood to comprise state activities that provide for the well-being of children and families with children. The following five conceptualisations of it still remain:

1. At its broadest, family policy is understood as a large collection of policies directed towards all families, also those without children. This approach is quite rare. Sometimes a difference is made between indirect and direct family policies (Kamerman \& Kahn 1978, Nobile 1994).

2. Family policy which takes into account all direct and indirect state policies (housing, education etc.) targeted at families with children (see Gornick et al. 1997). This is also called indirect policy.

3. Family policy which takes into account direct measures towards families with children. Direct family policy takes families as its aim and object (laws, income support mechanisms, direct services; see Kuusi, 1964, McDaniel 1990). To distinguish it from all other types of family policy, we will call it child and family policy.

4. Child policy - the internationally used framework for the term is based on the spirit of the United Nations Children's Rights Convention and means the protection of children's rights. Similar problems of vagueness apply to the definition of children's policy as well as that of family policy (see Ditch et al. 1998).

The paper analyses Estonian children and family policy using the content of the third approach.

\section{Institutions and general trends in Estonia}

The institutional set-up affects every policy (Weaver \& Rockman 1993). The existence or absence of special institutions is a sign of the importance and maturity of a policy and influences policy formation.

In the course of time, responsibility for children and family policy in Estonia has moved between several institutions. After World War II child and family problems were the responsibility of different People's Commissariats - Social Insurance, Labour, Education and Health, and Social Welfare (Leppik a and b). In that period, most Sovietperiod child and family policy programs were not explicitly designed to raise fertility but rather to improve living standards for the poorest families and to ease the burden of working mothers (see Jones \& Grupp 1987).

From 1950s the measures applied in Estonian family policy consisted mainly of cash benefits extended to large families, and the Ministry of Finance became the main institution to deal with it. In 1956, a department dealing with state benefits for prolific and unmarried mothers was transferred from under the jurisdiction of the Ministry of Fi- 
nance back to the Ministry of Social Insurance. From the 1970s, traditional measures such as child allowances, family vacations and birth grants were introduced (see Kõre 1999). An important indirect measure was state subsidies to child day-care and child commodities. As housing shortage was one of the most severe problems, an important role was that of preferences in housing assignments, where families with twins, large families, and single mothers were preferred.

In 1980s, fertility and permanence of Estonian families became important in public discussion. The initial document about Estonian development ("IME") contained one chapter about the main social policy measures (Tiit 1990a). The main object of discussion was the question of whether to introduce universal child allowances or to limit entitlement with some living period requirement.

A newspaper survey conducted in 1988 doesn't give a comprehensive overview of the entire population, but is still a rare and additional source of information in policy discussion. The results of 1,157 respondents showed that the most requested family policy measures were different forms of parental leave, benefits connected with it (employment record during three years, when the mother stays at home, maternity leave benefits, option to work part time) and housing (Tiit 1990b). The other public opinion survey from 1990 (Katus et al.) also stresses the importance of housing questions and reveals surprisingly low support for child allowances.

The restitution of the independence of Estonia in the 1990s and the concurrent socioeconomic changes brought about reorganisations in state structures. Gradually, one system of social insurance came to be replaced by another. 1990-1992 was a period during which Estonia had a Minister of Social Affairs and a Minister of Social Care working in parallel, the former dealing more with labour. The problems of family insurance belonged to the competence of the Minister of Social Care and his Ministry.

Finally, in 1993, the Ministry of Social Care, the Ministry of Health, and the Ministry of Labour were united to form the new Ministry of Social Affairs. The task of the new ministry was formulated as the development of social policy, including children and family policy. New problems like unemployment and insufficient subsistence demanded quick, new socio-political measures. According to the original plans the co-ordination of child protection was to be assigned to the Ministry of Education, whose competence at that time encompassed tutelage as well as many other children's issues. As the law was written, however, also child protection became the competence of the Ministry of Social Affairs. To this day, only day-care has remained in the competence of the Ministry of Education, being regarded as providing the children with primary education rather than a social service.

1994 was the international Year of the Family and brought about a lot of activities in the 
family area. Although the effect was mainly one of raising public awareness, the year was also favourable from a family policy point of view. In 1994, single grants to families with four children and school allowances were introduced. At the height of the Year's activities, a special Family Bureau was established at the Ministry of Social Affairs, functioning from 1995 to 1997. The tasks of the Bureau were concerned more with social care than social policy, dealing with trans-national adoption, services and legislation.

Many countries have special structures in their state organs designed to deal with family problems. One of the problems in Estonia has been the absence of such a structure. In 1996, the institution of the Population Minister, a minister without a portfolio, was introduced in Estonia. Both of the two Ministers hitherto in that office, however, have focused more on ethnic issues than on family problems.

Policy analysis and interviews with policy makers revealed that Estonian family policy bears a strong imprint of the personality and background of the particular minister and is considerably influenced by international organisations and consultants. The most influential foreign parties have been experts from Finland and Sweden, as well as the World Bank. One of the reasons for the dominance of political and foreign influences has certainly been the lack of professional civil servants, who, during the period of change, often found themselves in the role of students.

Instead of specialists working permanently in ministries, Estonian family policy has been very much in the hands of ad hoc commissions. In 1999 there were three such commissions (see Ainsaar 2000).

In the spring of 1999 a study on poverty, commissioned by the UN Development Programme, was published (Kutsar \& Trumm 1999), and later had a strong impact on the family policy discussion. This study brought wider attention to the poverty of families with children. In the same year, a newly manned Commission of Children and Family Policy worded the government's aim unequivocally as not simply raising the number of children, but rather raising the quality of life of children through the wellbeing of families with children. This was expected to encourage people to have children in the longer perspective (Laste ja perepoliitika alused 1999; Nestor 1999).

By the year 2000, Estonia managed a package of family policy measures with a structure typical to the East-European countries: birth allowance, parental leave, child care allowance, maternity leave, maternity benefits, school allowance, single parent allowance, foster care allowance, and conscript's child allowance. From the beginning of 2001, tax reductions, allowances for families with more than three children and for triples were additionally introduced and policy is becoming more clear-sighted. 
Figure 1. Rate of average family and child benefits to average old-age pension (\%)

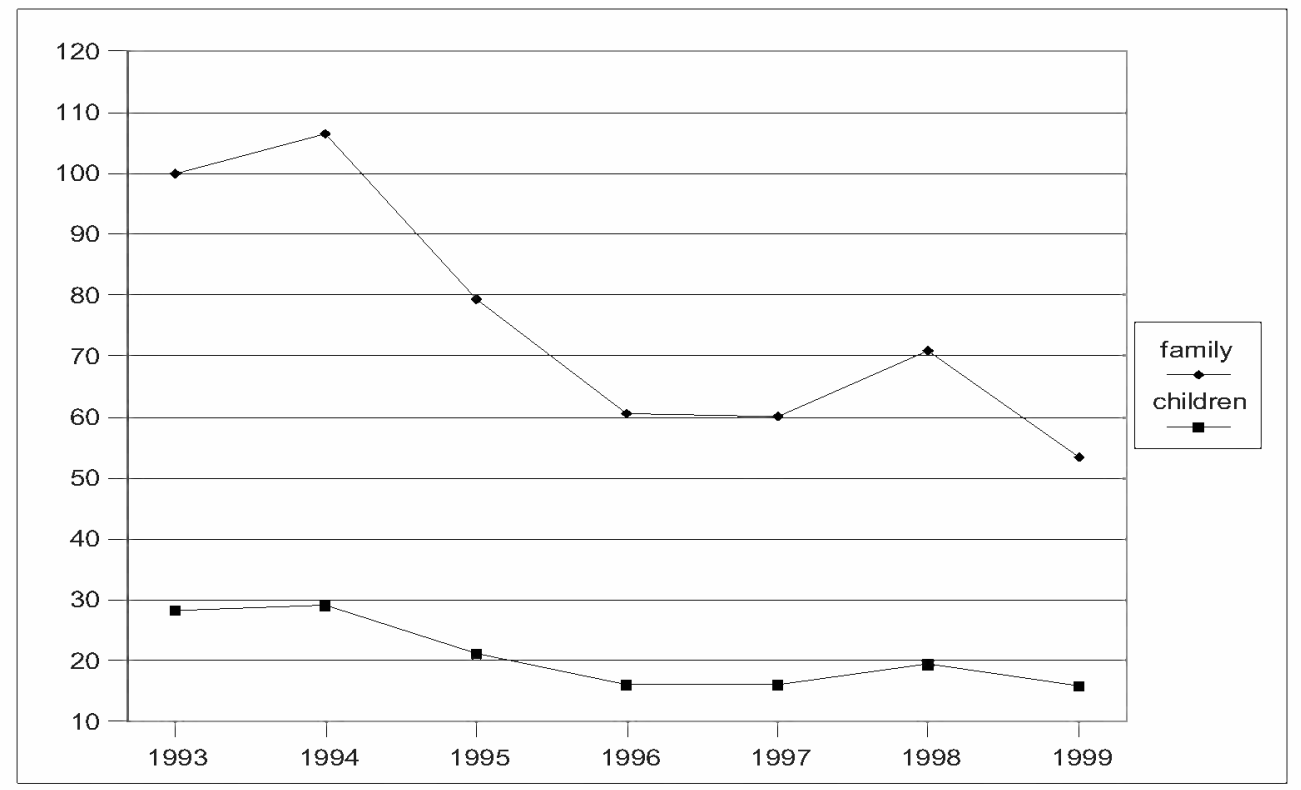

As a whole, the proportion of child and family benefits in the GNP has decreased since 1992, keeping near 1.5 per cent in recent years (Table 1). One reason for diminished expenditures is the decreased number children, as the birth rate has fallen considerably during the late $1990 \mathrm{~s}$.

Table 1. Share of family and child benefits in the GNP of Estonia

\begin{tabular}{lcccccccc}
\hline & $\mathbf{1 9 9 2}$ & $\mathbf{1 9 9 3}$ & $\mathbf{1 9 9 4}$ & $\mathbf{1 9 9 5}$ & $\mathbf{1 9 9 6}$ & $\mathbf{1 9 9 7}$ & $\mathbf{1 9 9 8}$ & $\mathbf{1 9 9 9}$ \\
\hline Family and child & & & & & & & & \\
allowances & 2.2 & 2.2 & 2.0 & 1.8 & 1.6 & 1.5 & 1.7 & 1.5 \\
Pensions & 5.3 & 6.6 & 6.4 & 7.0 & 7.6 & 7.2 & 7.1 & 8.5 \\
\hline
\end{tabular}

Even though the nominal value of the allowances has increased, their relative proportion to average wages and cost of living has dropped continuously. In 1992, child allowances made up nearly 16 per cent of the average wages. As the wages rose, this rate went down rapidly. Since 1992, all increases in child allowances have meant a delayed correction for catching up with the rising cost of living, rather than a real rise. The only exception was the real rise of the third child allowance that occurred in 1998. The development of child allowances has been parallel to that of the minimum level of subsistence, constituting about 30 per cent of its officially validated level. 
An analysis of the average benefit rate demonstrates that allowances for children and families have grown much more slowly than for example the second type of social insurance - the average old-age pension (Figure 1). In 1993, the average monthly pension was equal to the average family allowance. In 1998, the total of all family allowances made up 3/4 of the average pension. Hence, the main problem of the early $1990 \mathrm{~s}$ - poverty among pensioners - has been replaced by the subsistence of families with children. Large families and families with an unemployed parent have been hit the hardest (Tiit \& Käärik 2000).

Still, compared with other European countries, Estonian child allowances were at a medium level - rather good in relation to the average wage, but low in absolute terms in 1997 (Stropnik 2000).

Figure 2. Proportion of child allowances and the child care allowance to average gross wages $(\%)$.

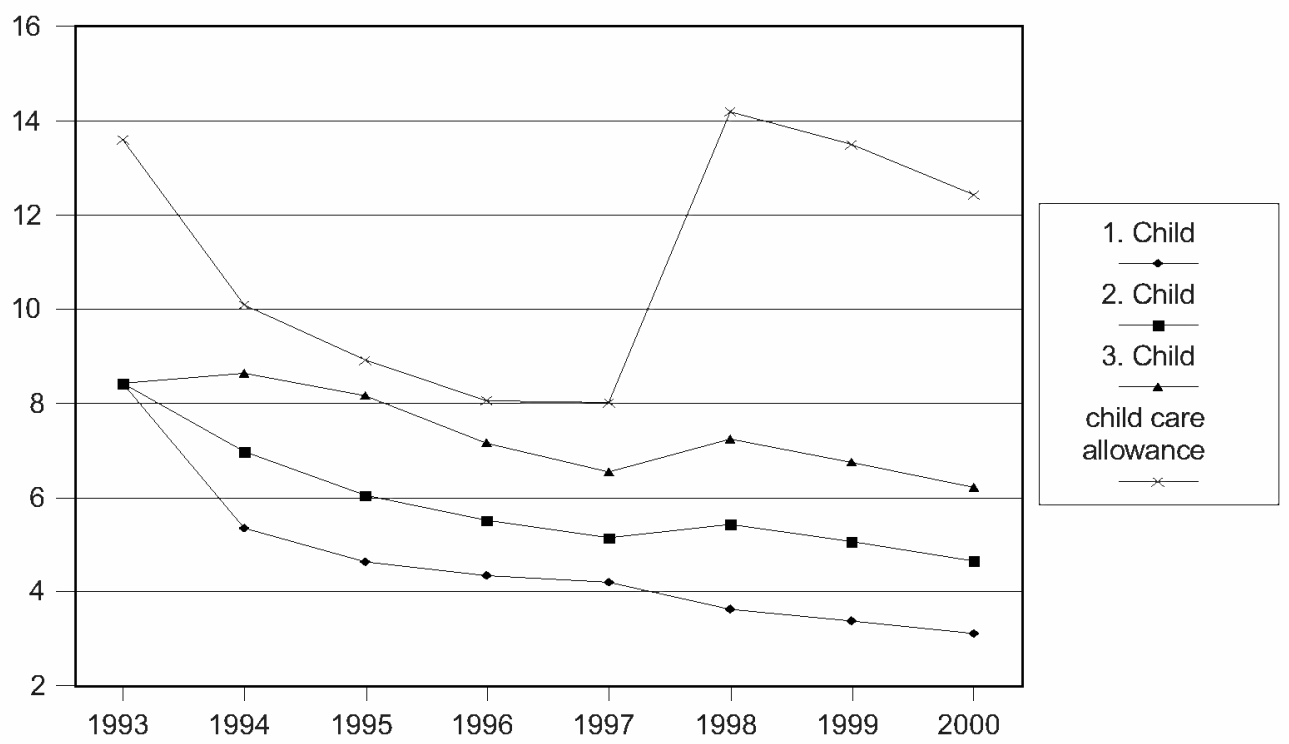

\section{Different child allowances}

The introduction of child allowances in Estonia happened at about the same time as in other European countries (see Wennemo 1994). Child allowances were at first selective by character and targeted only at the neediest families.

In 1945, only mothers of large families and single mothers were entitled to child allowances. Large family support was introduced after World War II, "large" taken to mean 
four or more children. This definition of "large family" has remained unchanged until now - it was not until 1999 that the first discussions occurred in government family policy about changing the classification of a large family from four to three children because of a changed demographic situation.

In 1945, the size of the allowance was dependent at first on the birth order of the child in the family, starting from 4 roubles allotted to the $4^{\text {th }}$ child and ending in 15 roubles paid to the $11^{\text {th }}$ (George 1991). According to A. Põldma (1998), entitlement to the large family child allowance was also dependent on the age of the child and was valid until the fourth or any subsequent child was 2-4 years old.

The second group entitled to child allowances were single mothers (birth certificate of children did not contain name of the father) and widows. When a single mother got married, the support was suspended. The aim of the state policy was to encourage single mothers to find their own jobs. Single mothers also had a prerogative to have the child taken to a day-care centre.

Since 1970, all allowances were dependent on the number of children and were paid until the child turned 5. In 1974 the support became means-tested, paid only if the family's monthly income was below EEK 50, to be paid until the child turned 8 (Põldma 1998). In 1981, child allowance became universal, but was still dependent on the birth order of the child and remained higher for children with a higher birth order.

In 1987-1989 Estonia witnessed a sharp increase in fertility. More third children were born than in previous years. This increase of births is often explained as a result of overall optimisms about the future and the so-called "singing revolution", and less significantly as a result of the supporting impact of local birth allowances. Local birth allowances were paid by firms and were often calculated to cover expenses for the child during the first free year.

A new Child Benefit Act became law in 1990. The act introduced universal child benefits, but only for children below 1.5 years. Children 1.5 to 6 years of age were entitled to allowances only if (1) the monthly income of the family was below EEK 140 per capita, and (2) the child did not attend a day-care centre. That same year a provision was introduced in the Labour Legislation entitling fathers who were raising their children without a mother's help to the same advantages in the workplace that previously only mothers used to have.

The new Child Benefits Act adopted in 1992 laid the foundation for a system of family support for eight years. An equal monthly allowance began to be paid for all children up to 15 years of age and to each day-school student up to 18 years of age. In November 1992, child benefits were tied to the minimum wage. This situation lasted until 1994, 
when the direct relationship between minimum wage and child allowances was cancelled because of diminished flexibility to increase one or the other.

A new Child Benefits Act was adopted in 1994. This time the preliminary discussions included the World Bank Poverty Project. The loaning conditions of the Bank required that family support should be given to poor families only. It was recommended that the beneficiary level be set at a level at which no poor family would go without support. In particular it was suggested that 50 per cent of the wealthy families should be excluded from the beneficiaries' circle, to increase the real amount of the allowances (Eesti... 1996). However, this idea was rejected by the Ministry of Social Affairs by arguing that a major share of families with children would have been entitled to those allowances anyway.

The 1994 Child Benefits Act based family policy on a child benefit rate (monthly allowance for one child) fixed by the Parliament in the State Budget. This disconnected child benefits from the minimum wages, thus giving both of them more freedom to rise whenever appropriate. The Act also required that the child benefit rate be changed if consumer prices should rise more than 10 per cent within half a year. The beneficiary's age qualification was raised to less than 16 and the child benefit rate was connected to birth order.

June 1994 brought an additional allowance to families with four or more children under age 16 (or school-children under 19), if one of the parents had to stay at home. Also, for those families, the maintenance allowance paid for each child under 3 years of age was raised. How exactly the allowance should reach the beneficiaries (equal or differentiated scheme, frequency of payment etc.) was left up to the counties to decide. The money was transferred to the County Social Care Departments for distribution.

In 1997, a new Bill of the Child Benefits Act was discussed in Parliament, but the necessary finances were not found. Again all alternatives, possibilities and criteria for the allotment of child allowances were reconsidered. As with each change in child allowance legislation, discussions were held on the criteria of selection of entitled persons, i.e. whether the allowances should be universal, means-tested, or dependent on birth order. The Child Benefits Act enacted in 1998 brought about an increase in almost all child benefits, most of all in the child-care allowance. The maintenance allowance for a parent nursing a child at home went only to the parent who stayed at home.

In terms of child allowances, connecting income tax with the number of children entered the public policy agenda already in 1998 (see Vilosius 1998), when several bills were presented to parliament. The Progressive Party, for example, moved that a full exemption from the income tax should depend on the birth of a third child, while a family with two children should have their income tax rate set at 13 per cent. At the 
same time the child allowances were meant to be reduced by about EEK 1 billion. According to bills submitted by the Union Party and the Patriotic Alliance, the monthly tax-free minimum would have been increased by EEK 500 per child. The idea descended from the argument that the State should hardly expropriate families off a certain sum just in order to return it to them later.

In the Parliamentary elections of 1999, the decline in fertility was a main concern of all political parties. The Cabinet that came into power in 1999 signed a coalition agreement that included the following rather concrete promises concerning families with children:

- Child-care allowance should be equal to the minimum wage by 2000 at the latest;

- No later than 2001 should the minimum wage exempted from the income tax be connected to the number of children in the family, while families with a low income should receive an additional allowance;

- $\quad$ An increase in the school allowances distributed by local authorities;

- Childbirth allowances, allowances to single parents and to the parents of disabled children should be increased;

- $\quad$ An Endowment of the Estonian Family should be established.

Later, during the implementation of the measures, many of them turned out to work straight against their initial aims.

The first step of the new government was to adopt a new Child Benefits Act, now under the name of the Family Benefits Act. The Act was enacted on 1 January 2000. The main difference compared to the previous Act was the replacement of the maintenance allowance with a more differentiated child-care allowance.

Another essential promise of the new government concerned the introduction of an income tax reduction. A public discussion on the issue took place during the State Budget debates in the spring of 2000 . The main point in dispute was whether all children should be taken into consideration in the income tax reduction (as had been first promised) or only the children beginning with the third child in the family. Soon all disadvantages of tax exemptions as compared with child allowances were brought to daylight. The positive aspects were believed to include a possible increase in work motivation and a necessary addition to the existing benefits.

During the 1990s a separate allowance for families with four or more children existed only temporarily in 1994-1995. From the beginning of 2001 they were reintroduced. 


\section{Parental leave and day-care}

Children, especially younger children, need care and supervision. In practise, the alternatives are bringing up children at home vs. organised day care. A good and affordable day-care service is considered important for child development as well as for providing families with equal opportunities.

Several surveys have studied the relationship between mothers' employment and fertility (Anker 1985; Jallinoja 1989; Burghes et al. 1999; Lutz 1999. Despite the lack of direct conclusions about the benefit of well-organised day-care or parental leave to fertility, organised care for smaller children still seems to be an important part of securing gender equality and the continuous participation of parents in social life. Well secured trade-off between parental leave and child care can have also other benefits for parents.

In a study on the relationship between female activity and fertility (1991) in five countries (France, Germany, UK, Sweden, Italy), none of the country reports found any evidence of a stable direct link between labour force participation and fertility in either direction. Time management was found to be an important aspect of decision making, particularly in coping with child-bearing and child development. It was found that the issues can be quality of child-care, which my be heavily conditioned by social attitudes, and the trade-off with economic security.

Parental leave has borne different names in Estonia: mothers' leave, maintenance allowance, child-care allowance. In 2000 , mothers were able to stay home approximately 70 days before childbirth and 70 days after - what is called pregnancy and delivery (maternity) leave. Any person taking care of a child until the child's third birthday is entitled to parental leave. Parental leave is extended to the mother or some other person to enable her/him to take care of a child at home. The leave may differ in the person(s) entitled, duration, and compensation.

Maternity leave and other measures targeted toward pregnant and nursing mothers are regulated in labour laws, and have remained unchanged from Soviet period. Parts of the laws have been the almost the same for several decades - statements like the ones that forbid employers to fire or lower the wages of such women, and that they are exempt from mandatory overtime and night work. Pregnant woman cannot be assigned to evening shifts, subjected to direct health hazards, or be sent on extended business trips.

The length of leave has changed several times. Before 1956, maternity leave generally lasted five weeks in the Soviet Union. In 1956 the period was changed to eight weeks. Until 1973 the maternity leave benefit was $2 / 3$ of the latest salary. 
The present Estonian parental leave system originates from 1973, when the maternity leave period was extended to 112 days (two months before and two months after delivery + an additional two weeks for difficult birth and twins), And The Maternity Leave Benefit Was Equalised With A Full Salary. For a four-month period, maternity leave was credited to the woman as uninterrupted employment which was important in terms of pension and social welfare rights. After this short period, the majority of mothers returned to work.

In 1984 it was stipulated for the first time that a mother had the right to stay on a paid parental care leave, which would not detract from her accrued years of employment and pension earning, until the child was one year old (Põldma 1998). Mother's leave and sick-leave compensations were the responsibility of the trade unions. Their primary aim was to provide the mother with income for a brief period of absence from work (George 1991).

The Child Benefit Act of 1990 enabled parental leave to be used also by a working member of the family other than the mother. In 1990 paid parental leave could be used until the child was one year old, and could be complemented by six months of unpaid leave. The state allowance was paid also if the mother worked part time (Põldma 1998). The leave was included in pension-earning employment even if the individual stayed at home until the child was 14 .

Next, the Child Benefit Act of 1992 extended paid parental leave up to the time the child was three years of age. The allowance was given to the mother regardless of whether she was working or not. The allowance depended on the minimum wage, constituting half of the minimum wage if the child was under 1.5 years old and 30 per cent of the minimum wage until the child was aged three.

The Child Benefit Act of 1994 substituted the child allowance rate for the minimum wage as the basis of child allowance.

The child allowance implemented in 2000 differs from the previous leave allowance in not requiring working mothers to stay at home. The beneficiary of the allowance may work either full time, part time, or, for example, at home. The aim was to enable the parent to earn a higher income as well as retain his/her qualifications and competitive abilities in the labour market (Pikhof 1999). According to the Act, the child-care allowance depended on who stayed at home with the child, the child's age, and the number of children in the family. The compensation was higher if either the mother or father stayed at home with it and if there was a child under three in the family.

In most cases motivation to stay at home with a younger child has been given in the form of a larger leave compensation (Table 2). Gradually the paid leave has also be- 
come longer. Since 2000, families with three or more children can receive a child-care allowance until the child becomes 8 . The difference between the compensation for staying at home with children under 2 and children 2-3 years of age was abolished. As the benefit does not depend on whether the parent is working or not, it actually functions as an additional child allowance.

Table 2. Proportion of various allowances (yearly average) to the average gross wages.

\begin{tabular}{|l|l|l|c|c|c|c|c|c|}
\hline & $\mathbf{1 9 9 3}$ & $\mathbf{1 9 9 4}$ & $\mathbf{1 9 9 5}$ & $\mathbf{1 9 9 6}$ & $\mathbf{1 9 9 7}$ & $\mathbf{1 9 9 8}$ & $\mathbf{1 9 9 9}$ & $\mathbf{2 0 0 0}$ \\
\hline Birth grant & 83.8 & 54.6 & 55.2 & 51.7 & 49.9 & $62.4^{* *}$ & $59.1^{*}$ & $77.7^{*}$ \\
\hline $\begin{array}{l}\text { Child-care allowance for } \\
\text { a child under 1.5 years }\end{array}$ & 13.6 & 10.0 & 8.9 & 8.0 & 8.0 & 14.2 & 13.3 & 12.4 \\
\hline $\begin{array}{l}\text { Child-care allowance for a } \\
\text { 1.5(2)-3-year-old child }\end{array}$ & 8.2 & 5.3 & 4.5 & 4.2 & 4.0 & 7.2 & 6.8 & 12.4 \\
\hline Single parent child allowance & 5.6 & 3.5 & 2.7 & 2.5 & 2.4 & 3.5 & 6.8 & 6.2 \\
\hline First child allowance & 8.4 & 5.4 & 4.6 & 4.6 & 4.2 & 3.6 & 3.4 & 3.1 \\
\hline
\end{tabular}

* Average of two different rates

** Calculated

\section{Day care}

Day care is one of the major services given to families with children. Despite the changes taking place in the society and the decrease in the number of children, the average proportion of children attending kindergarten has remained relatively stable (Table 3). In the mid-1980s there were long queues to place children in day care, but in the 1990s more children were raised at home and the queues shortened. By the end of the 1990s the proportion of children attending kindergarten began to go up again. According to the Pre-school Children Institution Act, all children ages 1-7 have the right to be placed in a local, municipal kindergarten as of July 2002. It should be pointed out that according to the Pre-school Institution Act, kindergartens are listed as educational institutions, not as part of social welfare services.

Table 3. Children in kindergarten

\begin{tabular}{lllllllll}
\hline & $\mathbf{1 9 8 0}$ & $\mathbf{1 9 8 5}$ & $\mathbf{1 9 9 0}$ & $\mathbf{1 9 9 5}$ & $\mathbf{1 9 9 6}$ & $\mathbf{1 9 9 7}$ & $\mathbf{1 9 9 8}$ & $\mathbf{1 9 9 9}$ \\
\hline $\begin{array}{l}\text { No. of children in } \\
\text { kindergarten (thousands) }\end{array}$ & 83,5 & 90,4 & 81,1 & 60,9 & 58,4 & 56,3 & 53,3 & 51,1 \\
\% of all 1-6-year-olds & 63 & 69 & 56 & 57 & 59 & 61 & 62 & 64 \\
Urban & 74 & 76 & 68 & 68 & 72 & 73 & 74 & 74 \\
Rural & 39 & 50 & 31 & 37 & 39 & 44 & 44 & 45 \\
\hline
\end{tabular}


The cost of day care has, no doubt, been a problem for many parents. Even though the maximum cost incurred by parents is regulated by law and cannot exceed 20 per cent of the current minimum wage (plus the cost of food), there are vast differences in the amounts that parents need to pay for child care. K. Forssén (1998) has revealed similar welfare inequality in her research in Finland.

A joint 1999 study financed by the Bureau of the Minister of Population and the Ministry of Social Affairs demonstrates that expenses per one child attending a kindergarten may differ up to ten-fold, depending on the local authorities (individual differences are even greater). The cost of a kindergarten spot stands in positive correlation with the size of the locality and food expenses, but not with the wealth of the local administration.

Parents' share of total kindergarten expenses is relatively small, on average 15 per cent of the total cost of a kindergarten spot and 4 per cent of average monthly gross wages. However, differences across localities can be remarkable (Table 4).

Many kindergartens have introduced a fee for teaching aids, which is fairly small. As for the so-called sharing fee it is more characteristic of urban than of rural areas, being higher in the former.

Table 4. Monthly kindergarten expenses per child in 1999 (means in EEK)

\begin{tabular}{|l|c|c|c|c|}
\hline & Rural & Urban & Mean & Standard deviation \\
\hline $\begin{array}{l}\text { Total cost of a } \\
\text { kindergarten spot }\end{array}$ & 1299 & 1338 & 1307 & 453,6 \\
\hline Cost of meals & 155 & 205 & 165 & 76,1 \\
\hline Parents' total share & 183 & 250 & 196 & 104,8 \\
\hline Parents' share of meals & 124 & 177 & 134 & 86,3 \\
\hline $\begin{array}{l}\text { Parents' share of } \\
\text { teaching aids and tuition }\end{array}$ & 23 & 29 & 24 & 25,7 \\
\hline Parents'sharing fee & 16 & 33 & 19 & 38,0 \\
\hline Other & 8 & 14 & 9 & 27,4 \\
\hline
\end{tabular}

Source: Special survey 


\section{Summary}

The article gives a brief overview of the development of children and family policy in Estonia. Children and family policy has changed according to different political systems. Although the aim of the paper was not to carry out a comprehensive comparative study, it is possible to make some general conclusions about the character of family policy in Estonia.

The early Estonian Soviet-period family policy is closest to the narrowly targeted policy (help only to the neediest families). At the same time, the general ideology of well-being of families was based mainly on full employment. Work participation was an important precondition for entitlement of family benefits, as many benefits were connected with the employment record. Even kindergartens were often arranged by work collectives.

In 1970-1990 several new benefits were introduced and a new approach toward a more generous family policy was taken. Estonian children and family policy was part of a general, comprehensive family policy in the USSR.

In terms of the 1990s, Nobile (1994) refers to a division of European countries into three groups according to their family policies: (1) Child-friendly countries directly oriented to fostering births (East-European countries, France, Luxembourg, Greece); (2) Countries with generous children's policies within the framework of a general aim of social and gender equality; (3) Countries where state benefits to families with children are rather modest, being confined to the families in greatest need (Great Britain and Ireland).

Changes in the political and economic structure of Estonia changed also the pattern of children's and family policy. Recent years have brought the clear shift of Estonian children's and family policy from the first group to the second. By economic, countrywide, comparative indicators it is still quite generous in spite of the fact that families with children are the group that experiences the most poverty.

In the decade between 1990 and 2000, Estonia has made rapid progress through different stages of child policy development, introduced new family benefits and created a whole new system. Several crucial problems related to family policy keep cropping up in discussions (tying income tax to the number of children, the principles of child allowance allotment, the functions and financing of day care). 
The policy bears traces of history, and different institutions and traditions. The main characteristics of today's children's and family policy are:

1) child benefits that are comparatively generous, but in absolute numbers pure

2) great dependency of policy on political decisions

3) development of initially plain and simple children's and family policy towards more something complicated.

Acknowledgements: The author is grateful for Helle Niit, Merle Malvet, Matti Mikkola, Eha Leppik, Sulev Piliste and Urve Randmaa, who all shared their memories and opinions about the formation of Estonian family policy.

\section{References}

Ainsaar, M. 2000. Eesti laste- ja perepoliitika otsingul, In: Laste- ja perepoliitika Eestis ja Euroopas, edited by M. Ainsaar, pp. 153-170. Tartu: Rahvastikuministri Büroo.

Ainsaar, M. and K. Oras. 2000. Laste arvu mõjutava tegurid, In: Ainsaar, M. (editor) Laste-ja perepoliitika Eestis ja Euroopas, edited by M. Ainsaar, pp. 112-133. Tartu: Rahvastikuministri Büroo.

Anker, R. 1985. Comparative survey. In: Working women in socialist countries: the fertility connection, edited by V. Bodrova, \& R. Anker, pp. 1-21. International Labour Office in Geneva.

Burghes, L., L. Clarke, S. Dex, S. Holtermann, M. Kozak, F. McGlone, J. Mountford, C. Roberts and F. Scheibl. 1999. Families and the labour market. In: Family \& Parenthood, Policy \& Practice, edited by S. Dex. Family Policy Studies Centre.

Chesnais, J-C. 1998. Below-replacement Fertility in the European Union (EU-15): Facts and policies, 1960-1997, Review of Population and Social Policy, No 7. pp. 83-101.

Cigno, A. 1991. Economics of the Family. Demographic development and social security, Fourth European Conference, Geneva, September 1987. Report II, International Labour Office Geneva. Clarendon Press, p. 212.

Ditch, J., H. Barnes, J. Bradshaw and M. Kilkey. 1998. Children: Status and policies in Europe. In: A Synthesis of National Family Policies in 1996, edited by John Ditch, Helen Barnes, Jonathan Bradshaw and Majella Kilkey, pp. 31-54. European Observatory on National Family Policies. York, UK: The University of York

Eesti: Elatustase üleminekul turumajandusele, toimetuleku hinnang 1996. Report No. 15647 EE, World Bank.

Forssèn, K. 1998. Decentralization of decision making: the case of payment policies for children's day-care, Scandinavian Journal of Social Welfare 7(27): 277-287.

Forssèn, K. 2000. Perepoliitikad ning laste majanduslik heaolu mõnedes OECD riikides. In: Laste- ja perepoliitika Eestis ja Euroopas, edited by M. Ainsaar, pp. 28-45. Tartu: Rahvastikuministri Büroo.

Gauthier, A. H. 1996. The state and the family. A comparative analysis of family policies in industrialized countries. Oxford: Clarendon Press. 
Gauthier, A. and J. \& Hatzius. 1997. Family benefits and fertility: An Enonomical analysis. Population Studies 51:295-306.

George, V. 1991. Social security in the USSR. International Social Security Review, Vol. 44,4 , pp. 47-65.

Gornick, J., M. Meyers and K. Ross. 1997. Supporting the employment of mothers: policy variation across fourteen welfare states, Journal of European Social policy, Vol. 7(1):4570.

Gustafsson, S. and T. Meisaari-Polsa. 1991. Why does fertility in Sweden increase? In: Study on the relationship between female activity and fertility, Vol. 1. Synthesis report, issues policy in the relationship between female activity and fertility, pp. 100-101. EUROSTAT and PA Cambridge Economic Consultants.

Hantrais, L. and M.-T. Letablier. 1996. Family policy making in Europe, Ch. 8. In: Families and family policies in Europe, edited by Linda Hantrais and Marie Thérèse Letablier, pp. 138-152. London: Longman.

Jallinoja, R. 1989. Women between the family and employment, In: Changing Patterns of European Family Life, edited by K. Boh, M. Bak, C. Clason, M. Pankratova, J. Qvortrup, G.B. Sgritta and K. Waerness, pp. 95-122. Routledge.

Jones, E. \& Grupp, F. 1987. Soviet demographic policies and fertility transition, Chapter 5, Modernisation value change and fertility in the Soviet Union, pp. 266-311. Cambridge: Cambridge University Press.

Kamerman, S. B. A. J. Kahn. 1993. Child and family benefits in Eastern and Central Europe and in the West: Learning from the transition, Environment and Planning: Government and Policy, 11, pp. 199-211.

Kangas, O. and V.-M. Ritakallio. 1998. Different methods - different results: approaches to multidimensional poverty. In: Empirical poverty research in a comparative perspective, edited by H.-J. Andress. Aldershot: Ashgate, pp. 167-203.

Kangas, O. 2000. Sotsiaalkindlustuse korralduse ja tulemuslikkuse võrdlus väljakujunenud ja üleminekumajandusega riikides. In: Laste- ja perepoliitika Eestis ja Euroopas, edited by M. Ainsaar, pp. 9-27. Tartu: Rahvastikuministri Büroo.

Katus, K., A. Puur and A. Vikat. 1990. Mida rahvas rahvastikupoliitikast arvab? Horisont 3, pp. 20-23.

Kutsar, D. \& Trumm, A. 1999. Vaesuse leevendamine Eestis: taust ja sihiseaded. Tartu: Tartu Ülikool.

Kuusi, P 1964. Family policy, social policy for the sixties. A plan for Finland. Finnish Social Policy Association.

Kõre, J. 1998. Sotsiaalkaitse Eestis, Eesti sotsiaalkaitse käsiraamat ja sõnastik, Consensus, Phare, pp. 73-93.

Laste ja perepoliitika alused (1999) www.riik.ee/pere/ (30.06.2000)

Leppik, E. (a) Sotsiaalministeeriumi osa Eesti sotsiaaltöö ajaloo kujunemisel, Ministry of Social Affairs, Manuscript.

Leppik, E. (b) Sotsiaalministeeriumi ajalugu (1918-1990), www.sm.ee (11.07.2000)

Lutz, W. 1999. Determinants of low fertility and ageing prospects for Europe. In: Family issues between gender and generations, seminar report edited by Sylvia Trnka, pp. 49-65. European Observatory on Family Matters. Luxembourg: Office for Official Publications of the European Communities.

McDaniel, S.A 1990. Towards Family Policies in Canada with Women in Mind. Canadian Research Institute for the Advancement of Women, Ottawa.

Nestor, E. 1999. Lastetoetus iivet ei tõsta. Postimees 20 September.

Nobile, A. 1994. The demographic and socio-economic context of childhearing. Directorate of Social and Economic Affairs. 
Pikhof, H. 1999. Kuidas väärtustada lapsi. Postimees, May 27.

Põldma, A. 1998. Sotsiaal- ja rahvastikupoliitika Eestis 91-94. Rahvastiku uuringud RU seeria B nr-26. Tallinn: EKDK.

Qvortrup, J. 1999. A childhood perspective applied to Wolfgang Lutz's paper, Family issues between gender and generations. In: Family Issues between gender and generations: seminar report, edited by Sylvia Trnka, pp. 70-73.. European Observatory on Family Matters, Vienna. Luxembourg: Office for Official Publications of the European Communities.

Study on the relationship between female activity and fertility. 1991. Vol. 1. Synthesis report, issues policy in the relationship between female activity and fertility, p.193. EUROSTAT and PA Cambridge Economic Consultants.

Sotsiaalministeeriumi haldusala arvudes. 1999. Tallinn: Ministry of Social Affairs.

Sotsiaalne kaitse. 1999. Eesti Statistika Aastaraamat, ESA 109.

Eurostat.1998. Statistics in focus. Population and social conditions 14/1998.

Stropnik, N. 2000. Lastetoetused ja lastega seotud maksusoodustused Euroopa riikides, In: Laste- ja perepoliitika Eestis ja Euroopas, edited by M. Ainssar, pp. 46-59. Tartu: Rahvastikuministri Büroo.

Tiit, E.-M. 1990a. Perekonnapoliitikast tänapäeva Eestis. In: Perekonnaproleemid IX, Eesti perekond ja perekonnaideaal, edited by A. Laas, pp. 4-18. Tartu: Tartu Ülikool.

Tiit, E.-M. 1990b. Ankeetküsitlus "Kuidas peaks riik abistama perekonda", Perekonnaprobleemid IX, Eesti perekond ja perekonnaideaal, edited by A.Laas, pp.19-37. Tartu: Tartu Ülikool.

Tiit, E.-M. and E. Käärik. 2000. Lastega leibkondade majanduslik toimetulek ja tüpoloogia. In: Laste- ja perepoliitika Eestis ja Euroopas, edited by M. Ainsaar, pp. 81-99. Tartu: Rahvastikuministri Büroo.

Weaver, R.K. and A. Rockman. 1993. Do Institutions Matter? Government Capabilities in the United States and Abroad, p. 481. The Brookings Institution.

Wennemo, I. 1992. The Development of Family Policy, A comparison of family benefits and Tax reductions for families in 18 OECD Countries, Acta Sociologica, 35:201-217.

Wennemo, I. 1994. Sharing the costs of children. Studies on the development of family support in the OECD countries. Swedish Institute for Social Research, 25.

Vilosius, T. 1998. Tulumaksusoodustus või lastetoetus? Päevaleht, October 17. 